\title{
Natural phytosanitary products effects on Bacillus thuringiensis subsp. kurstaki (Berliner)
}

\author{
Efeito de produtos fitossanitários naturais sobre Bacillus \\ thuringiensis subesp. kurstaki (Berliner)
}

\author{
Everton Ricardi Lozano da Silva ${ }^{1 *}$; Luis Francisco Angeli Alves ${ }^{2}$; Leonardo \\ Martinelo $^{3}$; Marina Andressa Fromentini'; Luiz Paulo Calixto Marchese ${ }^{3}$; Fabiana \\ Gisele Silva Pinto ${ }^{2}$; Michele Potrich ${ }^{1}$; Pedro Manuel Oliveira Janeiro Neves ${ }^{4}$
}

\begin{abstract}
This work aimed to evaluate the effect of natural phytossanitary products (NPP) on spores and crystal toxicity of Bacillus thuringiensis subsp. kurstaki-HD1 (Btk). For this commercial products (Agromos, Biogermex, Bovemax, Bordeaux mixture, Ecolife ${ }^{\circledR}$, Dalneen, Matan Plus, Pyronin and Stüble-Aid ${ }^{\circledR}$ ) were used at three different concentrations. The effect of NPP on spores was assessed by comparing a suspension of Btk + NPP with sterile distilled water (SDW) and another suspension with nutrient broth (NB), inoculated on nutrient agar (NA) in Petri dishes to quantify the number of CFU/mL, 18 $\mathrm{h}$ after inoculation and incubation. The effect of NPP on crystals was evaluated with a suspension of Btk+SDW+NPP added to the artificial diet supplied for Anticarsia gemmatalis Hub. (Lepidoptera: Noctuidae) quantifying the number of dead larvae at 12, 24, 48 and $72 \mathrm{~h}$. Matan Plus was the only natural product that did not present effect on spores. All other products, regardless of concentration, decreased significantly CFU/mL. Regarding crystals, Bordeaux mixture was the only one that reduced significantly Btk insecticidal activity at three concentrations.
\end{abstract}

Key words: Alternative control, entomopathogenic bacteria, integrated pest management

\section{Resumo}

Este trabalho objetivou avaliar o efeito dos produtos fitossanitários naturais (PFN) sobre esporos e sobre a toxicidade dos cristais de Bacillus thuringiensis subesp. kurstaki - HD1 (Btk). Para tal foram usados os produtos comerciais (Agromos, Biogermex, Bovemax, Calda Bordalesa, Ecolife ${ }^{\circledR}$, Dalneen, Matan Plus, Pironin e Stuble $-\mathrm{Aid}^{\circledR}$ ) em três diferentes concentrações. O efeito dos PFN sobre esporos foi avaliado comparando-se suspensões de Btk + PFN com água destilada esterelizada (ADE) e suspensões com caldo nutriente $(\mathrm{CN})$, inoculadas em ágar nutriente (AN) em placas de Petri, quantificando-se o número de unidades formadoras de colônias (UFC / mL), 18 h após a inoculação e incubação. O efeito dos PFN sobre cristais foi avaliado com suspensões de Btk + ADE + PFN adicionados à dieta artificial fornecida para Anticarsia gemmatalis Hub. (Lepidoptera: Noctuidae), quantificando-se o número de lagartas mortas nos tempos 24, 48 e $72 \mathrm{~h}$. Matan Plus foi o único produto natural que não apresentou

${ }^{1}$ D.Sc., Profs. da Universidade Tecnológica Federal do Paraná, UTFPR, Câmpus Dois Vizinhos, Dois Vizinhos, PR. E-mail: evertonlricardi@utfpr.edu.br; michelepotrich@utfpr.edu.br

2 D.Sc., Profs. do Centro de Ciências Biológicas e da Saúde, Universidade Estadual do Oeste do Paraná, UNIOESTE, Câmpus de Cascavel, Cascavel, PR. E-mail: luis.alves@unioeste.br; fabiana.pinto@unioeste.br

3 Biólogos, UNIOESTE, Câmpus de Cascavel, Cascavel, PR. E-mail: leonardomartinelo@gmail.com; marinaformentini@hotmail. com; lupacama@gmail.com

${ }^{4}$ D.Sc., Prof. do Dept ${ }^{\mathrm{o}}$ de Agronomia, Centro de Ciências Agrárias, Universidade Estadual de Londrina, UEL, Londrina, PR. E-mail: pedroneves@uel.br

* Author for corespondence 
efeito sobre esporos. Todos os outros produtos, independentemente da concentração, diminuíram significativamente as UFC/mL. Com relação aos cristais, a Calda Bordalesa foi o único produto que reduziu significativamente a atividade inseticida de Btk nas três concentrações.

Palavras-chave: Controle alternativo, bactérias entomopatogênicas, manejo integrado de pragas

\section{Introduction}

Phytossanitary products are often applied in conventional or alternative agricultural systems with the objective to enhance crop yield, however, the excessive and inappropriate use of those products is dangerous to health. Consumers aware of this danger search for "cleaner" food nowadays. Therefore, NPP - natural phytossanitary products - have been the scope of researchers to find alternatives that can ensure agriculture sustainability and consumers demands.

Entomopathogens are important natural factors of the environment that regulate insectpests populations (LACEY et al., 2001), such as Bacillus thuringiensis (Bt) that due to biological characteristics, stands out as the main bacteria used in biocontrol (ANGELO; VILAS-BÔAS; CASTRO-GÓMEZ, 2010) and can be applied alone or in association to phytossanitari products and NPP as formulated biopesticide in traditional and alternative crops systems.

However, the action of microbial control agents can be stimulated, supressed or unchanged after association with phytossanitary products. These products may inhibit growth, reproduction, cause mutations, and even inactivate microorganisms, decreasing virulence to a particular pest (ALVES; MOINHO JUNIOR; ALMEIDA, 1998).

Several studies have been conducted to verify the interaction between chemical products and entomopathogenic bacteria. Different techniques can be used to evaluate the effects of chemical products on spores of $B$. thutingiensis subsp. thuringiensis (Btk) such as paper disks impregnation technique with broth products (DOUGHERTY; REICHELDERFER; FAUST, 1971; JIMENEZ; ACOSTA; FERNANDEZ, 1989) and with liquid culture medium (SUTTER et al., 1971, CHEN et al., 1974), and mixing products to the molten culture medium technique from the works of Salerno, Dias and Sagardoy (1999), Batista Filho; Almeida and Lamas (2001), Almeida et al. (2003) and Gassen, Batista Filho and Zappelini (2006). The effects of chemical products on Btk using different techniques was studied by Silva et al. $(2006,2008)$ and the results varied according to chemical group, technique used, concentration, contact time, and development stage of the pathogen.

Studying natural phytossanitary products, Krischik, Barbosa and Reichelderfer (1988) evaluated the effect of nicotine and rutin on $\mathrm{Bt}$ and observed that both reduced growth and germination and only nicotine affected Manduca sexta toxicity. When non-sporulating bacteria and plant extracts were studied, rosemary (Rosmarinus officinalis) presented negative effect on Staphylococcus aureus and Bacillus cereus when evaluated at different times and concentrations (GENENA et al., 2008), whereas rue (Ruta graveolens) inhibited growth of several bacteria species, including the genus Bacillus (PEREIRA et al., 2006; MENDES et al., 2008).

Given the above, further studies are needed concerning phytossanitary products effects on Bt since there are few information about this interactions, especially with NPP considered safer than conventional ones. This study was performed to evaluated the effects of natural phytossanitary products on spores and on toxicity of $B$. thuringiensis subsp. kurstaki against Anticarsia gemmatalis under laboratory conditions.

\section{Material and Methods}

Bacillus thuringiensis subsp. kurstaki HD-1 (Btk) obtained from the commercial product Dipel 
$\mathrm{PM}^{\circledR}$ was used. NPP samples were obtained from commercial products (Table 1) and the evaluations were made with the following concentrations: recommended concentration of the product $(\mathrm{RC})$, half that concentration $(1 / 2 \mathrm{RC})$ and twice that concentration (2RC).
Larvae of Anticarsia gemmatalis (Lepidoptera: Noctuidae) were obtained from the laboratory culture, in containers with artificial diet, according to Hoffmann-Campo, Oliveira and Moscardi (1985), maintained at $26 \pm 2{ }^{\circ} \mathrm{C}$, RH: $70 \% \pm 10 \%$ and $14 \mathrm{~h}$ photoperiod until the larvae reach the second instar.

Table 1. Commercial name, composition, use and recommended concentration of natural products used in the experiments.

\begin{tabular}{|c|c|c|c|}
\hline Product & Composition & Use & $\begin{array}{c}\text { Recommended } \\
\text { concentration } / \mathrm{ha}^{1}\end{array}$ \\
\hline Agro-Mos ${ }^{\circledR}$ & $\begin{array}{c}\text { Cell wall of Saccharomyces cerevisiael } \\
\text { oligosaccharides }\end{array}$ & Resistance inducer & $1.5 \mathrm{~L}$ \\
\hline Biogermex & $\begin{array}{l}\text { Citrus bioflavonoids (vitamin P), } \\
\text { phytoalexins citric, ascorbic acid } \\
\text { (vitamin C), citric acid, polypeptides } \\
\text { citric, palmitic acid, various fatty acid, } \\
\text { sugars, glicerydes and tocopherols }\end{array}$ & $\begin{array}{l}\text { Bactericide / } \\
\text { Fungicide }\end{array}$ & $0.2 \mathrm{~L}$ \\
\hline Bovemax & $\begin{array}{l}\text { Beauveria bassiana conidia } \\
\text { Emulsionnable Oil formulation }\end{array}$ & Insecticide & $1 \mathrm{~L}$ \\
\hline Bordeaux Mixture & $\begin{array}{l}\text { Lime and copper sulfate } 1 \mathrm{Kg} \mathrm{CuSO} 4+ \\
1 \mathrm{Kg} \mathrm{Cal}\end{array}$ & Fungicide & \\
\hline Ecolife $^{\circledR}$ & $\begin{array}{l}\text { Bioflavonoids, fitoalexins, ascorbic, } \\
\text { lactic and citric acids }\end{array}$ & Resistance inducer & $0.75 \mathrm{~L}$ \\
\hline Dalneem & Azadirachta indica oil seed & Insecticide & $1 \mathrm{~L}$ \\
\hline Matan Plus & Sulfur and nitrogen & Insecticide & \\
\hline Pironim & $\begin{array}{l}\text { Azadirachta indica oil seed, rotenone, } \\
\text { pyrethrum, allamanda, Black pepper } \\
\text { and pyroligneous extract }\end{array}$ & Insecticide & $0.6 \mathrm{~L}$ \\
\hline Stubble-Aid ${ }^{\circledR}$ & $\begin{array}{l}\text { Copper sulfate }(28.0 \mathrm{~g} / \mathrm{L}) \text {; Ferrous } \\
\text { sulfate }(51.6 \mathrm{~g} / \mathrm{L}) ; \text { Manganese } \\
\text { sulfate }(12.0 \mathrm{~g} / \mathrm{L}) ; \text { Zinc sulfate }(42.0 \mathrm{~g} / \mathrm{L})\end{array}$ & Biofertilizer & $1 \mathrm{~L}$ \\
\hline
\end{tabular}

${ }^{1}$ Concentration recommended by the manufacturer, standardized at $100 \mathrm{~L} /$ hectare.

Source: Elaboration of the authors.

\section{NPP Effect on Btk spores}

NPP mixed with sterile distilled water. A bacterial suspension $\left(3.75 \times 10^{4}\right.$ spores $\left./ \mathrm{mL}\right)$ in 20 $\mathrm{mL}$ of sterile distilled water (SDW) was prepared. This suspension was diluted and aliquots of $300 \mu \mathrm{L}$ $\left(5.6 \times 10^{3}\right.$ spores $\left./ \mathrm{mL}\right)$ were added to Erlenmeyer flasks containing $50 \mathrm{~mL}$ SDW mixed with the NPP at the different concentrations.
NPP mixed with nutrient broth. Bacterial suspension was prepared with the same procedure described in the previous section but instead of SDW, nutrient broth (NB) was used.

Five Erlenmeyer flasks (replicates) were used for both experiments and for each NPP tested concentration (treatment). Water was used for the control treatment. Flasks were incubated in 
horizontal shaker $\left(30 \pm 2{ }^{\circ} \mathrm{C}, 150 \mathrm{rpm}\right.$ for $\left.2 \mathrm{~h}\right)$ and $\mathrm{pH}$ was measured prior and subsequent to incubation. Five points ( $5 \mu \mathrm{L} /$ point) from each flask were inoculated on the surface of nutrient agar (NA) in three Petri dishes (ALVES; MORAES, 1998). Inoculated Petri dishes were kept open in laminar flow chamber for five minutes to evaporate the excess of water and, after that, dishes were closed and incubated in acclimatized chamber $\left(30 \pm 2{ }^{\circ} \mathrm{C}\right)$ during $18 \mathrm{~h}$. The number of colony-forming units (CFU) per point was counted and the final result was expressed in CFU/mL.

\section{NPP effect on crystal toxicity}

Bacterial suspension was prepared with $31.3 \times$ $10^{9}$ spores $/ \mathrm{mL}$ in SDW. Samples of $10 \mathrm{~mL}\left(1.5 \times 10^{9}\right.$ spores $/ \mathrm{mL}$ ) from this suspension were transferred to Erlenmeyer flasks containing $40 \mathrm{~mL}$ of SDW and NPP at the different concentrations, then these flasks were incubated as described above. The $\mathrm{pH}$ was measured prior to incubation and at the end of incubation.

Subsequently, $150 \mu \mathrm{L}$ aliquots of the suspension $\left(4.5 \times 10^{7}\right.$ spores $\left./ \mathrm{mL}\right)$ were added in about 1.5 $\mathrm{cm}$ on the side surface of artificial diet cubes for A. gemmatalis in Petri dishes that were kept open in laminar flow chamber for about 15 minutes to evaporate the excess of water and, after that, each Petri dish received 25 second-instar larvae of A. gemmatalis. All treatments consisted of five replicates, with a Petri dish each one. Identical batches were prepared for control, with larvae receiving NPP at the three tested concentrations and Btk suspension separately in diet. Also, an absolute control group was assembled with larvae supplied with the artificial diet treated only with sterile water. The dishes were placed in acclimatized chamber (26 $\pm 2{ }^{\circ} \mathrm{C}, \mathrm{RH}: 70 \% \pm 10 \%$ and $14 \mathrm{~h}$ photophase) and the evaluations were recorded at 12,24, 48 and $72 \mathrm{~h}$, quantifying the number of dead caterpillars. Death caused by Btk was confirmed with the observation of larvae symptoms and pathogen signs as described by Habib and Andrade (1998).

\section{Data analysis}

Data was submitted to analysis of variance ( $F$ test) and means were compared among themselves by Tukey test, both at 5\% significance, using the Sisvar software program (FERREIRA, 2007). When needed, data was previously transformed into to be analyzed.

\section{Results and Discussion}

NPP Effect on the Btk spores

NPP mixed with sterile distilled water. Stubble$\mathrm{Aid}^{\circledR}$ decreased CFU/mL as concentration increased, whereas Matan Plus did not decrease CFU/mL in any concentration. All other products, regardless of concentration, decreased significantly CFU/ $\mathrm{mL}$ presenting variation between $12.8 \%$ and $100 \%$ when compared to control treatment (Table 2).

NPP mixed with nutrient broth. Agro-Mos ${ }^{\mathbb{B}}$ decreased $\mathrm{CFU} / \mathrm{mL}$ as concentration increased, whereas other products presented a significant negative effect ranging from $29.6 \%$ to $100 \%$ (Table $3)$. 
Table 2. B. thuringiensis subsp. kurstaki HD-1 CFU/mL means $( \pm \mathrm{SE})$ from spores obtained from commercial product after incubation $\left(30 \pm 2{ }^{\circ} \mathrm{C}, 150 \mathrm{rpm}, 2 \mathrm{~h}\right)$ with sterile distilled water and alternative products at different concentrations and initial and final $\mathrm{pH}$.

\begin{tabular}{|c|c|c|c|c|c|}
\hline \multirow{2}{*}{ Treatment } & \multirow{2}{*}{ Conc. ${ }^{1}$} & \multirow{2}{*}{ Average CFU/mL $\left(\mathrm{x} 10^{5}\right)$} & \multirow{2}{*}{ CFU Rel. Test $(\%)^{2}$} & \multicolumn{2}{|c|}{$\mathrm{pH}$} \\
\hline & & & & Oh & $2 \mathrm{~h}$ \\
\hline Control & - & $265.1 \pm 17.41 \mathrm{a}$ & - & 6.46 & 6.61 \\
\hline Agro-Mos ${ }^{\circledR}$ & $1 / 2 \mathrm{RC}$ & $168.0 \pm 7.88 b$ & -40.8 & 3.72 & 3.72 \\
\hline Agro-Mos ${ }^{\circledR}$ & $\mathrm{RC}$ & $142.4 \pm 17.58 b$ & -49.8 & 3.61 & 3.55 \\
\hline Agro-Mos ${ }^{\circledR}$ & $2 \mathrm{RC}$ & $47.2 \pm 10.84 \mathrm{c}$ & -83.4 & 3.48 & 3.40 \\
\hline $\mathrm{CV}(\%)=$ & & 20.21 & & & \\
\hline Control & - & $279.1 \pm 17.12 \mathrm{a}$ & - & 6.46 & 6.61 \\
\hline Biogermex & $1 / 2 \mathrm{RC}$ & $13.5 \pm 3.34 b$ & -95.2 & 4.08 & 4.02 \\
\hline Biogermex & $\mathrm{RC}$ & $0.0 \pm 0.00 \mathrm{~b}$ & -100.0 & 3.76 & 3.67 \\
\hline Biogermex & $2 \mathrm{RC}$ & $0.0 \pm 0.00 \mathrm{~b}$ & -100.0 & 3.48 & 3.54 \\
\hline $\mathrm{CV}(\%)=$ & & 26.7 & & & \\
\hline Control & - & $338.7 \pm 12.23 \mathrm{a}$ & - & 6.46 & 6.61 \\
\hline Bovemax & $1 / 2 \mathrm{RC}$ & $275.5 \pm 9.42 b$ & -18.7 & 5.99 & 6.79 \\
\hline Bovemax & $\mathrm{RC}$ & $295.4 \pm 11.88 b$ & -12.8 & 5.97 & 6.72 \\
\hline Bovemax & $2 \mathrm{RC}$ & $282.7 \pm 6.5 b$ & -16.5 & 5.99 & 6.55 \\
\hline $\mathrm{CV}(\%)=$ & & 7.7 & & & \\
\hline Control & - & $241.2 \pm 18.55 \mathrm{a}$ & - & 6.46 & 6.61 \\
\hline Bordeaux misture & $1 / 2 \mathrm{RC}$ & $31.7 \pm 6.75 b$ & -86.8 & 12.5 & 12.09 \\
\hline Bordeaux misture & $\mathrm{RC}$ & $0.0 \pm 0.00 \mathrm{~b}$ & -100.0 & 12.6 & 12.28 \\
\hline Bordeaux misture & $2 \mathrm{RC}$ & $0.0 \pm 0.00 \mathrm{~b}$ & -100.0 & 12.6 & 12.35 \\
\hline $\mathrm{CV}(\%)=$ & & 32.34 & & & \\
\hline Testemunha & - & $333.6 \pm 21.6 \mathrm{a}$ & - & 6.46 & 6.61 \\
\hline Ecolife $^{\circledR}$ & $1 / 2 \mathrm{RC}$ & $0.0 \pm 0.00 \mathrm{~b}$ & -100.0 & 3.83 & 3.80 \\
\hline Ecolife $^{\circledR}$ & $\mathrm{RC}$ & $0.0 \pm 0.00 \mathrm{~b}$ & -100.0 & 3.73 & 3.78 \\
\hline Ecolife $^{\circledR}$ & $2 \mathrm{RC}$ & $0.0 \pm 0.00 \mathrm{~b}$ & -100.0 & 3.42 & 3.36 \\
\hline $\mathrm{CV}(\%)=$ & & 28.96 & & & \\
\hline Control & - & $305.33 \pm 12.89 \mathrm{a}$ & - & 6.46 & 6.61 \\
\hline Matan Plus & $1 / 2 \mathrm{RC}$ & $309.6 \pm 17.24 \mathrm{a}$ & 1.4 & 4.78 & 5.68 \\
\hline Matan Plus & $\mathrm{RC}$ & $313.6 \pm 9.00 \mathrm{a}$ & 2.7 & 5.02 & 5.53 \\
\hline Matan Plus & $2 \mathrm{RC}$ & $308.0 \pm 20.57 \mathrm{a}$ & 0.9 & 5.18 & 5.41 \\
\hline $\mathrm{CV}(\%)=$ & & 10.55 & & & \\
\hline Control & - & $233.0 \pm 12.76 \mathrm{a}$ & - & 6.46 & 6.61 \\
\hline Dalneem & $1 / 2 \mathrm{RC}$ & $2.3 \pm 1.29 b$ & -98.7 & 4.94 & 4.89 \\
\hline Dalneem & $\mathrm{RC}$ & $0.0 \pm 0.00 \mathrm{~b}$ & -100.0 & 4.77 & 4.84 \\
\hline Dalneem & $2 \mathrm{RC}$ & $0.0 \pm 0.00 \mathrm{~b}$ & -100.0 & 4.66 & 4.78 \\
\hline $\mathrm{CV}(\%)=$ & & 23.1 & & & \\
\hline Control & - & $262.1 \pm 21.55 \mathrm{a}$ & - & 6.46 & 6.61 \\
\hline Pironim & $1 / 2 \mathrm{RC}$ & $185.1 \pm 7.56 b$ & -29.4 & 3.66 & 3.58 \\
\hline Pironim & $\mathrm{RC}$ & $199.2 \pm 13.69 b$ & -24.0 & 3.49 & 3.46 \\
\hline Pironim & $2 \mathrm{RC}$ & $185.1 \pm 7.56 b$ & -29.4 & 3.31 & 3.30 \\
\hline $\mathrm{CV}(\%)=$ & & 14.89 & & & \\
\hline Control & & $282.4 \pm 7.49 a$ & - & 6.46 & 6.61 \\
\hline Stubble Aid $^{\circledR}$ & $1 / 2 \mathrm{RC}$ & $223.9 \pm 8.95 b$ & -20.7 & 3.56 & 3.61 \\
\hline Stubble Aid $^{\circledR}$ & $\mathrm{RC}$ & $151.2 \pm 14.29 \mathrm{c}$ & -46.5 & 3.47 & 3.40 \\
\hline Stubble Aid $^{\circledR}$ & $2 \mathrm{RC}$ & $49.7 \pm 10.53 \mathrm{~d}$ & -82.4 & 3.30 & 3.21 \\
\hline $\mathrm{CV}(\%)=$ & & 15.1 & & & \\
\hline
\end{tabular}

Means $( \pm$ SE) followed by the same letter in column do not differ significantly by the Tukey test $(\mathrm{P}<0.05)$.

${ }^{1}$ Product concentration: $1 / 2 \mathrm{RC}=$ Half the recommended concentration, $\mathrm{RC}=$ Recommended concentration; $2 \mathrm{RC}=\mathrm{Twice}$ the recommended concentration. ${ }^{2}$ Formula: [(Treatment Average CFU/ml / Control Average CFU/mL $\left.\left.\times 100\right)-100\right]$, with positive values to $\mathrm{CFU} / \mathrm{mL}$ increase and negative values for reduction when compared to the control.

Source: Elaboration of the authors. 
Table 3. B. thuringiensis subsp. kurstaki $\mathrm{HD}-1 \mathrm{CFU} / \mathrm{mL}$ means ( $\pm \mathrm{ASE}$ ) from spores obtained from commercial product after incubation $\left(30 \pm 2{ }^{\circ} \mathrm{C}, 150 \mathrm{rpm}, 2 \mathrm{~h}\right)$ with nutrient broth and alternative products at different concentrations and initial and final $\mathrm{pH}$.

\begin{tabular}{|c|c|c|c|c|c|}
\hline \multirow{2}{*}{ Treatment } & \multirow{2}{*}{ Conc. ${ }^{1}$} & \multirow{2}{*}{ Average CFU/mL $\left(\mathrm{x} 10^{5}\right)$} & \multirow{2}{*}{ CFU Rel. Test $(\%)^{2}$} & \multicolumn{2}{|c|}{$\mathrm{pH}$} \\
\hline & & & & $0 \mathrm{~h}$ & $2 \mathrm{~h}$ \\
\hline Control & - & $526.1 \pm 26.38 \mathrm{a}$ & 0.0 & 7.54 & 7.47 \\
\hline Agro-Mos ${ }^{\circledR}$ & $1 / 2 \mathrm{RC}$ & $212.1 \pm 9.99 b$ & -59.7 & 4.29 & 4.31 \\
\hline Agro-Mos ${ }^{\circledR}$ & $\mathrm{RC}$ & $115.5 \pm 13.92 \mathrm{c}$ & -78.1 & 4.13 & 4.07 \\
\hline Agro-Mos ${ }^{\circledR}$ & $2 \mathrm{RC}$ & $18.7 \pm 9.13 \mathrm{~d}$ & -96.5 & 3.97 & 3.72 \\
\hline $\mathrm{CV}(\%)=$ & & 19.1 & & & \\
\hline Control & - & $565.6 \pm 23.31 \mathrm{a}$ & 0.0 & 7.54 & 7.47 \\
\hline Biogermex & $1 / 2 \mathrm{RC}$ & $0.0 \pm 0.00 \mathrm{~b}$ & -100.0 & 7.19 & 7.18 \\
\hline Biogermex & $\mathrm{RC}$ & $0.0 \pm 0.00 \mathrm{~b}$ & -100.0 & 7.16 & 7.16 \\
\hline Biogermex & $2 \mathrm{RC}$ & $0.0 \pm 0.00 \mathrm{~b}$ & -100.0 & 7.02 & 7.20 \\
\hline $\mathrm{CV}(\%)=$ & & 18.4 & & & \\
\hline Control & - & $232.5 \pm 22.62 \mathrm{a}$ & 0.0 & 7.54 & 7.47 \\
\hline Bovemax & $1 / 2 \mathrm{RC}$ & $152.1 \pm 9.99 b$ & -34.6 & 7.30 & 7.27 \\
\hline Bovemax & $\mathrm{RC}$ & $157.9 \pm 8.62 b$ & -32.1 & 7.34 & 7.32 \\
\hline Bovemax & $2 \mathrm{RC}$ & $163.7 \pm 9.86 \mathrm{~b}$ & -29.6 & 7.34 & 7.43 \\
\hline $\mathrm{CV}(\%)=$ & & 18.83 & & & \\
\hline Control & - & $446.1 \pm 21.29 \mathrm{a}$ & 0.0 & 7.54 & 7.47 \\
\hline Bordeaux mixture & $1 / 2 \mathrm{RC}$ & $39.5 \pm 11.67 b$ & -91.2 & 11.87 & 11.66 \\
\hline Bordeaux mixture & $\mathrm{RC}$ & $0.3 \pm 0.27 b$ & -99.9 & 12.26 & 11.81 \\
\hline Bordeaux mixture & $2 \mathrm{RC}$ & $0.0 \pm 0.00 \mathrm{~b}$ & -100.0 & 12.34 & 12.09 \\
\hline $\mathrm{CV}(\%)=$ & & 22.4 & & & \\
\hline Control & - & $562.9 \pm 18.13 a$ & 0.0 & 7.54 & 7.47 \\
\hline Ecolife $^{\circledR}$ & $1 / 2 \mathrm{RC}$ & $0.0 \pm 0.00 \mathrm{~b}$ & -100.0 & 7.24 & 7.06 \\
\hline Ecolife $^{\circledR}$ & $\mathrm{RC}$ & $0.0 \pm 0.00 \mathrm{~b}$ & -100.0 & 7.11 & 6.94 \\
\hline Ecolife $^{\circledR}$ & $2 \mathrm{RC}$ & $0.0 \pm 0.00 \mathrm{~b}$ & -100.0 & 6.77 & 6.70 \\
\hline $\mathrm{CV}(\%)=$ & & 14.1 & & & \\
\hline Control & - & $312.5 \pm 26.38 \mathrm{a}$ & 0.0 & 7.54 & 7.47 \\
\hline Matan Plus & $1 / 2 \mathrm{RC}$ & $288.4 \pm 11.6 \mathrm{a}$ & -7.7 & 7.30 & 7.50 \\
\hline Matan Plus & $\mathrm{RC}$ & $340.9 \pm 11.7 \mathrm{a}$ & 9.1 & 7.29 & 7.22 \\
\hline Matan Plus & $2 \mathrm{RC}$ & $281.8 \pm 16.47 \mathrm{a}$ & -9.8 & 7.24 & 7.14 \\
\hline $\mathrm{CV}(\%)=$ & & 28.07 & & & \\
\hline Control & - & $432.7 \pm 33.83 a$ & 0.0 & 7.54 & 7.47 \\
\hline Dalneem & $1 / 2 \mathrm{RC}$ & $0.4 \pm 0.40 \mathrm{~b}$ & -99.9 & 4.94 & 4.89 \\
\hline Dalneem & $\mathrm{RC}$ & $0.0 \pm 0.00 \mathrm{~b}$ & -100.0 & 4.77 & 4.84 \\
\hline Dalneem & $2 \mathrm{RC}$ & $0.0 \pm 0.00 \mathrm{~b}$ & -100.0 & 4.66 & 4.78 \\
\hline $\mathrm{CV}(\%)=$ & & 34.9 & & & \\
\hline Control & - & $339.2 \pm 15.93 \mathrm{a}$ & 0.0 & 7.54 & 7.47 \\
\hline Pironim & $1 / 2 \mathrm{RC}$ & $176.5 \pm 14.26 b$ & -48.0 & 6.23 & 6.55 \\
\hline Pironim & $\mathrm{RC}$ & $171.7 \pm 16.2 b$ & -49.4 & 5.34 & 5.35 \\
\hline Pironim & $2 \mathrm{RC}$ & $147.5 \pm 6.95 b$ & -56.5 & 4.83 & 4.76 \\
\hline $\mathrm{CV}(\%)=$ & & 24.2 & & & \\
\hline Control & & $471.3 \pm 8.67 \mathrm{a}$ & 0.0 & 7.54 & 7.47 \\
\hline Stubble-Aid $^{\circledR}$ & $1 / 2 \mathrm{RC}$ & $72.8 \pm 7.60 \mathrm{~b}$ & -84.6 & 4.77 & 4.68 \\
\hline Stubble-Aid $^{\circledR}$ & $\mathrm{RC}$ & $43.8 \pm 2.94 \mathrm{c}$ & -90.7 & 4.22 & 4.34 \\
\hline Stubble-Aid $^{\circledR}$ & $2 \mathrm{RC}$ & $20.3 \pm 4.69 c$ & -95.7 & 3.98 & 4.06 \\
\hline $\mathrm{CV}(\%)=$ & & 9.4 & & & \\
\hline
\end{tabular}

Means $( \pm$ SE) followed by the same letter in column do not differ significantly by the Tukey test $(\mathrm{P}<0.05)$.

${ }^{1}$ Product concentration: $1 / 2 \mathrm{RC}=$ Half the recommended concentration, $\mathrm{RC}=$ Recommended concentration; $2 \mathrm{RC}=\mathrm{Twice}$ the recommended concentration. ${ }^{2}$ Formula: [(Treatment Average CFU/ml / Control Average CFU/mL $\left.\left.\times 100\right)-100\right]$, with positive values to $\mathrm{CFU} / \mathrm{mL}$ increase and negative values for reduction compared to the control.

Source: Elaboration of the authors. 
Biogermex and Ecolife ${ }^{\circledR}$ decreased CFU/ $\mathrm{mL}$ at $100 \%$ whereas Dalneem and Bordeaux mixture decreased over $90 \%$ regardless of tested concentration, when compared to control treatment. Stubble-Aid ${ }^{\circledR}$ decreased $84.6 \%$ at $1 / 2$ RC, $90.7 \%$ at $\mathrm{RC}$ and $95.7 \%$ at $2 \mathrm{RC}$. Likewise, Pironim presented similar CFU/mL decrease at all concentrations: $48.0 \%, 49.4 \%$ and $56.5 \%$. Still, Bovemax reduced $\mathrm{CFU} / \mathrm{mL}$ at all tested concentrations ranging from $29.6 \%$ to $34.6 \%$ (Table 3 ).

Regardless of incubation time, $\mathrm{pH}$ of treatments ranged from 3.21 (Stublle-Aid - 2RC) to 12.35 (Bordeaux mixture - 2RC), observing reduction of $\mathrm{CFU} / \mathrm{mL}$ both to treatments with acidic $\mathrm{pH}$ as well as for to treatments with neutral and basic $\mathrm{pH}$ (Tables 2 and 3).

Biogermex and Ecolife ${ }^{\circledR}$ must be emphasized because when mixed with water presented acidic $\mathrm{pH}$ and when mixed with NB presented neutral $\mathrm{pH}$ similar to the control treatment, and in both cases $\mathrm{CFU} / \mathrm{mL}$ decreased, indicating that the observed result was caused by some other factor than $\mathrm{pH}$ (Tables 2 and 3). According to instructions of manufacturer, Ecolife ${ }^{\circledR}$ consists of bioflavonoids, citric phytoalexins and ascorbic acid, similar composition of Biogermex. Flavonoids and terpenoids are molecules derived from the secondary metabolism of plants, which act as a defense mechanism against insects and pathogens (DIXON; DEY; LAMB, 1983; COWAN, 1999). Moreover, according to Tsuchiya et al. (1996), flavonoids have the ability of binding to cell wall, inactivating them and disrupting membranes.

The decrease of $\mathrm{CFU} / \mathrm{mL}$ observed from Biogermex and Ecolife ${ }^{\circledR}$ are very noteworthy and may be related to the impediment of germination process or the destructive action on bacterial membrane after germination. Such negative effect on cells can be assured with the study with Ecolife $^{\circledR}$ and cells of Ralstonia solanacearum and Xanthomonas axonopodis pv. manihotis (Gramnegative pathogenic bacteria), the results showed that the inhibition halo was proportional to the increase of product concentration (MOTOYAMA et al., 2003). Similarly, the negative effect caused by Pironim seems not to be related to $\mathrm{pH}$, because $\mathrm{pH}$ was close to the control treatment when mixed with $\mathrm{NB}$ at $1 / 2 \mathrm{RC}$ and $\mathrm{CFU} / \mathrm{mL}$ also decreased. Thus, this observation may be related to product composition, in which neem (Azadirachta indica), rotenone, pyrethrum, allamanda, black pepper and pyroligneous extract are included. According to Venkat et al. (2004) the antimicrobial activity exerted by neem is added by the alkyl piperidine present in black pepper that also has bactericidal property.

Agro-Mos $^{\circledR}$ also caused significant CFU/ $\mathrm{mL}$ decrease at acidic $\mathrm{pH}$, both when mixed with SDW as with NB (Tables 2 and 3). This product is a resistance inducer, and acts directly on the plant that becomes more tolerant to pests. Due to this mechanism of action, no work has been reported concerning the application of this product directly on any pathogen. The decrease of CFU/mL due to Dalneem may have occurred because this product is composed by neem (Azadirachta indica), a plant composed by several constituents such as flavonoids that has antimicrobial action (MOSSINI; KEMMELMEIER, 2005). These results corroborate Alzoreky and Nakahara (2003) who observed Bacillus cereus inhibition of growth when exposed to methanol and acetic extracts of neem flowers.

Unlike other products, Bordeaux mixture, presented $\mathrm{pH}$ values near 12 when mixed with water or NB. But, in this case, Bordeaux mixture components, such as lime and copper sulfate, may also have contributed to the inhibition of CFU/mL. Hassen et al. (1998) studied the Bt tolerance to copper at six concentrations, and observed that the highest concentration was able to inhibit bacteria growth almost at full. In addition, Gassen, Batista Filho and Zappelini (2006) studied fungicides based on another copper form (copper oxychloride) and also observed Btk incompatibility with them all. 
Stubble-Aid $^{\circledR}$, as well as other liquid biofertilizers, is rich in metabolites such as enzymes, antibiotics, vitamins, toxins, phenols, esters and acids that act as nutrient for plants, and still present acaricidal, fungistatic and bacteriostatic activity (GALLO et al., 2002), which may explain the observed negative effect proportional to concentration.

Bovemax, regardless of concentration, reduced the CFU/mL both when mixed with SDW and NB. This product is formulated with conidia of the entomopathogenic fungus Beauveria bassiana, vegetable oil and emulsifier. Morris (1975) observed that $\mathrm{Bt}$ spores germination decrease when exposed to some emulsifiers. Considering that this fungus does not affect $\mathrm{Bt}$, the emulsifier must have been responsible for the observed negative effects on spores.

There are not specific studies about the effects of natural products on spores of Bacillus thuringiensis. The limited information available in literature refers to the effect of natural products on several bacteria regarding vegetative growth, therefore further specific studies are needed to understand the action of these products on Btk spores germination and CFU.

\section{NPP effect on crystal toxicity}

Only Bordeaux mixture inhibited crystal toxicity at all concentrations, differing significantly from the control treatment with Btk only. The other products did not affect crystal toxicity related to the total percentage of dead larvae (Table 4). Bovemax, at the three concentrations, Biogermex in the $\mathrm{RC}+$ Btk and 2RC + Btk and Agro-Mos ${ }^{\circledR}$ in the $\mathrm{CR}+\mathrm{Btk}$ caused partial negative effect on the crystal toxicity, with mortality decreased at $48 \mathrm{~h}$, differing only from the control treatment with Btk.
Stubble-Aid ${ }^{\circledR}$ presented positive effect on $2 \mathrm{RC}$ + Btk at $48 \mathrm{~h}$, with higher mean of larval mortality percentage, differing significantly from other treatments with Btk (Table 4). Ecolife ${ }^{\circledR}$, Matan Plus, Dalneem and Pironim caused no adverse effects on crystal toxicity.

Biogermex and Dalneem presented no significant differences in mortality between 48 and $72 \mathrm{~h}$ in treatment $2 \mathrm{RC}+\mathrm{Btk}$, differently from the absolute control group with Btk and other treatments with Btk, which presented more dead larvae at $48 \mathrm{~h}$ (Table 4).

Bovemax at the three concentrations + Btk presented mortality reduction at $48 \mathrm{~h}$ with no difference between evaluations at 48 and $72 \mathrm{~h}$, whereas the control treatment with Btk presented the highest mortality at $48 \mathrm{~h}$. Still, regarding the Stubble-Aid $^{\circledR}$, the control treatment with Btk presented higher percentage of dead larvae at $72 \mathrm{~h}$, unlike $2 \mathrm{RC}+\mathrm{Btk}$ which the highest percentage was observed at $48 \mathrm{~h}$, while in concentrations $1 / 2 \mathrm{RC}+$ Btk and RC + Btk no difference between 48 and 72 $\mathrm{h}$ was observed.

Matan Plus at the $\mathrm{RC}+\mathrm{Btk}$ and $2 \mathrm{RC}+\mathrm{Btk}$ presented higher mortality rate at $48 \mathrm{~h}$, whereas the control with Btk and the product at $1 / 2 \mathrm{RC}+\mathrm{Btk}$ showed no significant difference between 48 and 72 h.

Most products affected negatively the CFU/ $\mathrm{mL}$, but only Bordeaux mixture inhibited crystals toxicity. Bordeaux mixture $(\mathrm{pH} \approx 12)$ was the only product with $\mathrm{pH}$ above 7.5 , and the only that impaired Btk ability to kill caterpillars, therefore the $\mathrm{pH}$ can explain this result. According to Batista Filho et al. (1998) pH values above 7 and near 11 are detrimental to the Bt. The lack of crystals toxicity after incubation with Bordeaux mixture may be related to crystal dissolution in alkaline medium not fully activating or even deactivating proteins. 
Table 4. Total percentage means ( $\pm \mathrm{SE})$ of A.gemmatalis larvae mortality caused by $B$. thuringiensis subsp. kurstaki HD-1 at 12, 24, 48 and 72 hours after incubation $\left(30 \pm 2{ }^{\circ} \mathrm{C}, 150 \mathrm{rpm}, 2 \mathrm{~h}\right)$ with sterile distilled water and alternative products at different concentrations and initial and final $\mathrm{pH}$.

\begin{tabular}{|c|c|c|c|c|c|c|c|}
\hline \multirow[b]{2}{*}{ Treatment } & \multicolumn{5}{|c|}{ Time } & \multicolumn{2}{|c|}{$\mathrm{pH}$} \\
\hline & $12 \mathrm{~h}$ & $24 \mathrm{~h}$ & $48 \mathrm{~h}$ & $72 \mathrm{~h}$ & $\begin{array}{c}\text { Total } \\
\text { mortality }(\%)^{1}\end{array}$ & Oh & $2 \mathrm{~h}$ \\
\hline \multicolumn{8}{|l|}{ Agro-Mos ${ }^{\circledR}$} \\
\hline $\begin{array}{l}\text { Control } \\
\text { Water }\end{array}$ & $0.0 \pm 0.00 \mathrm{Aa}$ & $0.8 \pm 0.80 \mathrm{Aa}$ & $0.0 \pm 0.00 \mathrm{Da}$ & $0.8 \pm 0.80 \mathrm{Ba}$ & $1.6 \pm 0.98 \mathrm{~B}$ & 6.22 & 6.37 \\
\hline Control $1 / 2 \mathrm{RC}$ & $0.0 \pm 0.00 \mathrm{Aa}$ & $0.8 \pm 0.80 \mathrm{Aa}$ & $0.0 \pm 0.00 \mathrm{Da}$ & $0.8 \pm 0.80 \mathrm{Ba}$ & $1.6 \pm 1.60 \mathrm{~B}$ & 3.63 & 3.55 \\
\hline Control RC & $0.0 \pm 0.00 \mathrm{Aa}$ & $0.8 \pm 0.80 \mathrm{Aa}$ & $2.4 \pm 1.60 \mathrm{CDa}$ & $0.0 \pm 0.00 \mathrm{Ba}$ & $3.2 \pm 1.96 \mathrm{~B}$ & 3.50 & 3.45 \\
\hline Control 2RC & $0.0 \pm 0.00 \mathrm{Aa}$ & $0.0 \pm 0.00 \mathrm{Aa}$ & $0.0 \pm 0.00 \mathrm{Da}$ & $0.0 \pm 0.00 \mathrm{Ba}$ & $0.0 \pm 0.91 \mathrm{~B}$ & 3.34 & 3.32 \\
\hline Control Btk & $0.0 \pm 0.00 \mathrm{Ac}$ & $0.8 \pm 0.80 \mathrm{Ac}$ & $36.4 \pm 5.20 \mathrm{Ab}$ & $58.8 \pm 5.63 \mathrm{Aa}$ & $96.0 \pm 1.79 \mathrm{~A}$ & 5.24 & 5.38 \\
\hline $1 / 2 \mathrm{RC}+\mathrm{Btk}$ & $0.8 \pm 0.80 \mathrm{Ac}$ & $0.0 \pm 0.00 \mathrm{Ac}$ & $24.8 \pm 4.80 \mathrm{ABb}$ & $65.6 \pm 5.15 \mathrm{Aa}$ & $91.1 \pm 2.94 \mathrm{~A}$ & 3.89 & 3.88 \\
\hline $\mathrm{RC}+\mathrm{Btk}$ & $1.6 \pm 1.60 \mathrm{Ac}$ & $0.8 \pm 0.80 \mathrm{Ac}$ & $12.3 \pm 5.76 \mathrm{BCb}$ & $56.0 \pm 14.03 \mathrm{Aa}$ & $70.7 \pm 10.08 \mathrm{~A}$ & 3.79 & 3.73 \\
\hline $2 R C+B t k$ & $3.2 \pm 1.96 \mathrm{Ac}$ & $0.8 \pm 0.80 \mathrm{Ac}$ & $20.8 \pm 5.99 \mathrm{ABb}$ & $66.4 \pm 4.83 \mathrm{Aa}$ & $91.2 \pm 4.08 \mathrm{~A}$ & 3.61 & 3.54 \\
\hline CV 1 $(\%)=$ & 37.3 & $\mathrm{CV} 2(\%)=$ & 43.5 & CV $3(\%)=$ & 16.5 & & \\
\hline \multicolumn{8}{|l|}{ Biogermex } \\
\hline $\begin{array}{l}\text { Control } \\
\text { Water }\end{array}$ & $0.0 \pm 0.00 \mathrm{Aa}$ & $0.0 \pm 0.00 \mathrm{Aa}$ & $0.0 \pm 0.00 \mathrm{Ca}$ & $0.0 \pm 0.00 \mathrm{Ca}$ & $0.0 \pm 0.00 \mathrm{~B}$ & 6.22 & 6.37 \\
\hline Control $1 / 2 \mathrm{RC}$ & $0.0 \pm 0.00 \mathrm{Aa}$ & $0.0 \pm 0.00 \mathrm{Aa}$ & $0.8 \pm 0.77 \mathrm{Ca}$ & $1.5 \pm 0.92 \mathrm{Ca}$ & $2.3 \pm 0.92 \mathrm{~B}$ & 3.93 & 3.99 \\
\hline Control RC & $0.0 \pm 0.00 \mathrm{Aa}$ & $0.0 \pm 0.00 \mathrm{Aa}$ & $0.0 \pm 0.00 \mathrm{Ca}$ & $0.0 \pm 0.00 \mathrm{Ca}$ & $0.0 \pm 0.00 \mathrm{~B}$ & 3.89 & 4.01 \\
\hline Control 2RC & $0.0 \pm 0.00 \mathrm{Aa}$ & $0.8 \pm 0.80 \mathrm{Aa}$ & $0.0 \pm 0.00 \mathrm{Ca}$ & $4.8 \pm 3.88 \mathrm{BCa}$ & $5.6 \pm 3.71 \mathrm{~B}$ & 3.51 & 3.50 \\
\hline Control Btk & $0.7 \pm 0.67 \mathrm{Ab}$ & $4.6 \pm 2.04 \mathrm{Ab}$ & $88.7 \pm 4.07 \mathrm{Aa}$ & $6.0 \pm 4.85 \mathrm{BCb}$ & $100.0 \pm 0.00 \mathrm{~A}$ & 5.24 & 5.38 \\
\hline $1 / 2 \mathrm{RC}+\mathrm{Btk}$ & $2.3 \pm 1.58 \mathrm{Abc}$ & $5.4 \pm 2.74 \mathrm{Abc}$ & $81.3 \pm 3.68 \mathrm{Aa}$ & $11.0 \pm 4.40 \mathrm{Bb}$ & $100.0 \pm 0.00 \mathrm{~A}$ & 4.34 & 4.47 \\
\hline $\mathrm{RC}+\mathrm{Btk}$ & $2.4 \pm 1.00 \mathrm{Ac}$ & $3.2 \pm 1.96 \mathrm{Ac}$ & $67.9 \mathrm{~A} \pm 3.53 \mathrm{Ba}$ & $25.7 \pm 3.09 \mathrm{Ab}$ & $99.2 \pm 0.76 \mathrm{~A}$ & 4.04 & 4.09 \\
\hline $2 \mathrm{RC}+\mathrm{Btk}$ & $0.8 \pm 0.80 \mathrm{Ab}$ & $3.2 \pm 1.55 \mathrm{Ab}$ & $51.7 \pm 6.19 \mathrm{Ba}$ & $43.3 \pm 6.93 \mathrm{Aa}$ & $99.2 \pm 0.76 \mathrm{~A}$ & 3.77 & 3.81 \\
\hline CV $1(\%)=$ & 26.2 & CV $2(\%)=$ & 35.9 & CV $3(\%)=$ & 11.8 & & \\
\hline \multicolumn{8}{|l|}{ Bovemax } \\
\hline $\begin{array}{l}\text { Control } \\
\text { Water }\end{array}$ & $0.0 \pm 0.00 \mathrm{Aa}$ & $0.0 \pm 0.00 \mathrm{Aa}$ & $0.0 \pm 0.00 \mathrm{Ca}$ & $0.0 \pm 0.00 \mathrm{Ba}$ & $0.0 \pm 0.00 \mathrm{~B}$ & 6.22 & 6.37 \\
\hline Control $1 / 2 \mathrm{RC}$ & $0.8 \pm 0.83 \mathrm{Aa}$ & $0.0 \pm 0.00 \mathrm{Aa}$ & $0.0 \pm 0.00 \mathrm{Ca}$ & $0.0 \pm 0.00 \mathrm{Ba}$ & $0.8 \pm 0.84 \mathrm{~B}$ & 5.55 & 5.54 \\
\hline Control RC & $0.8 \pm 0.80 \mathrm{Aa}$ & $0.0 \pm 0.00 \mathrm{Aa}$ & $0.0 \pm 0.00 \mathrm{Ca}$ & $0.0 \pm 0.00 \mathrm{Ba}$ & $0.8 \pm 0.80 \mathrm{~B}$ & 5.65 & 5.32 \\
\hline Control 2RC & $0.0 \pm 0.00 \mathrm{Aa}$ & $1.0 \pm 0.95 \mathrm{Aa}$ & $3.6 \pm 2.20 \mathrm{Ca}$ & $0.0 \pm 0.00 \mathrm{Ba}$ & $4.5 \pm 2.93 \mathrm{~B}$ & 5.63 & 5.73 \\
\hline Control Btk & $0.7 \pm 0.67 \mathrm{Ab}$ & $4.6 \pm 2.04 \mathrm{Ab}$ & $88.7 \pm 4.07 \mathrm{Aa}$ & $6.0 \pm 4.85 \mathrm{Bb}$ & $100 \pm 0.00 \mathrm{~A}$ & 5.24 & 5.38 \\
\hline $1 / 2 \mathrm{RC}+\mathrm{Btk}$ & $3.1 \pm 0.78 \mathrm{Ab}$ & $1.5 \pm 1.48 \mathrm{Ab}$ & $44.1 \pm 10.3 \mathrm{Ba}$ & $43.8 \pm 7.20 \mathrm{Aa}$ & $92.5 \pm 4.20 \mathrm{~A}$ & 5.43 & 5.52 \\
\hline $\mathrm{RC}+\mathrm{Btk}$ & $2.4 \pm 1.59 \mathrm{Ab}$ & $1.6 \pm 0.96 \mathrm{Ab}$ & $43.5 \pm 13.68 \mathrm{Ba}$ & $45.3 \pm 11.56 \mathrm{Aa}$ & $92.8 \pm 3.13 \mathrm{~A}$ & 5.80 & 5.83 \\
\hline $2 \mathrm{RC}+\mathrm{Btk}$ & $6.6 \pm 2.54 \mathrm{Ab}$ & $2.5 \pm 1.62 \mathrm{Ab}$ & $46.9 \pm 8.34 \mathrm{Ba}$ & $32.8 \pm 6.01 \mathrm{Aa}$ & $88.8 \pm 6.08 \mathrm{~A}$ & 5.39 & 5.54 \\
\hline CV $1(\%)=$ & 45.4 & CV $2(\%)=$ & 44.9 & CV $3(\%)=$ & 13.1 & & \\
\hline \multicolumn{8}{|c|}{ Bordeaux mixture } \\
\hline $\begin{array}{l}\text { Control } \\
\text { Water }\end{array}$ & $0.0 \pm 0.00 \mathrm{Aa}$ & $0.0 \pm 0.00 \mathrm{Aa}$ & $0.0 \pm 0.00 \mathrm{Ba}$ & $1.0 \pm 1.00 \mathrm{BCa}$ & $1.0 \pm 1.00 \mathrm{~B}$ & 6.22 & 6.37 \\
\hline Control $1 / 2 \mathrm{RC}$ & $0.0 \pm 0.00 \mathrm{Aa}$ & $0.0 \pm 0.00 \mathrm{Aa}$ & $0.0 \pm 0.00 \mathrm{Ba}$ & $1.0 \pm 0.96 \mathrm{BCa}$ & $1.0 \pm 0.96 \mathrm{~B}$ & 12.54 & 12.13 \\
\hline Control RC & $0.0 \pm 0.00 \mathrm{Aa}$ & $0.0 \pm 0.00 \mathrm{Aa}$ & $0.0 \pm 0.00 \mathrm{Ba}$ & $0.0 \pm 0.00 \mathrm{Ca}$ & $0.0 \pm 0.00 \mathrm{~B}$ & 12.62 & 12.25 \\
\hline Control 2RC & $0.0 \pm 0.00 \mathrm{Ab}$ & $0.0 \pm 0.00 \mathrm{Ab}$ & $0.0 \pm 0.00 \mathrm{Bb}$ & $2.8 \pm 1.17 \mathrm{ABa}$ & $2.8 \pm 2.82 \mathrm{~B}$ & 12.63 & 12.27 \\
\hline Control Btk & $0.0 \pm 0.00 \mathrm{Ac}$ & $0.0 \pm 0.00 \mathrm{Ac}$ & $88.7 \pm 6.69 \mathrm{Aa}$ & $7.6 \pm 3.30 \mathrm{Ab}$ & $96.3 \pm 3.70 \mathrm{~A}$ & 5.24 & 5.38 \\
\hline $1 / 2 \mathrm{RC}+\mathrm{Btk}$ & $0.0 \pm 0.00 \mathrm{Aa}$ & $0.0 \pm 0.00 \mathrm{Aa}$ & $0.0 \pm 0.00 \mathrm{Ba}$ & $0.0 \pm 0.00 \mathrm{Ca}$ & $0.0 \pm 0.00 \mathrm{~B}$ & 12.25 & 11.78 \\
\hline $\mathrm{RC}+\mathrm{Btk}$ & $0.0 \pm 0.00 \mathrm{Aa}$ & $0.0 \pm 0.00 \mathrm{Aa}$ & $0.0 \pm 0.00 \mathrm{Ba}$ & $0.0 \pm 0.00 \mathrm{Ca}$ & $0.0 \pm 0.00 \mathrm{~B}$ & 12.44 & 12.08 \\
\hline $2 \mathrm{RC}+\mathrm{Btk}$ & $0.0 \pm 0.00 \mathrm{Aa}$ & $0.0 \pm 0.00 \mathrm{Aa}$ & $1.0 \pm 1.00 \mathrm{Ba}$ & $0.9 \pm 0.91 \mathrm{BCa}$ & $1.9 \pm 1.17 \mathrm{~B}$ & 12.41 & 12.24 \\
\hline CV 1 $(\%)=$ & 29.1 & CV $2(\%)=$ & 38.4 & CV $3(\%)=$ & 33.5 & & \\
\hline \multicolumn{8}{|l|}{ Ecolife $^{\circledR}$} \\
\hline $\begin{array}{l}\text { Control } \\
\text { Water }\end{array}$ & $0.0 \pm 0.00 \mathrm{Aa}$ & $0.0 \pm 0.00 \mathrm{Ba}$ & $0.0 \pm 0.00 \mathrm{Ba}$ & $0.0 \pm 0.00 \mathrm{Ba}$ & $0.0 \pm 0.00 \mathrm{~B}$ & 6.22 & 6.37 \\
\hline Control $1 / 2 \mathrm{RC}$ & $0.0 \pm 0.00 \mathrm{Aa}$ & $0.0 \pm 0.00 \mathrm{Ba}$ & $0.0 \pm 0.00 \mathrm{Ba}$ & $0.0 \pm 0.00 \mathrm{Ba}$ & $0.0 \pm 0.00 \mathrm{~B}$ & 3.55 & 3.44 \\
\hline Control RC & $0.0 \pm 0.00 \mathrm{Aa}$ & $0.0 \pm 0.00 \mathrm{Ba}$ & $0.0 \pm 0.00 \mathrm{Ba}$ & $2.7 \pm 2.73 \mathrm{Ba}$ & $2.7 \pm 2.72 \mathrm{~B}$ & 3.54 & 3.43 \\
\hline
\end{tabular}


Silva, E. R. L. da et al.

continuation

\begin{tabular}{|c|c|c|c|c|c|c|c|}
\hline Control 2RC & $0.0 \pm 0.00 \mathrm{Aa}$ & $0.9 \pm 0.91 \mathrm{Ba}$ & $0.9 \pm 0.91 \mathrm{Ba}$ & $0.9 \pm 0.87 \mathrm{Ba}$ & $2.7 \pm 1.81 \mathrm{~B}$ & 3.30 & 3.25 \\
\hline Control Btk & $3.9 \pm 3.10 \mathrm{Ac}$ & $7.2 \pm 1.32 \mathrm{Ac}$ & $70.6 \pm 3.37 \mathrm{Aa}$ & $17.4 \pm 2.19 \mathrm{Ab}$ & $99.1 \pm 0.86 \mathrm{~A}$ & 5.24 & 5.38 \\
\hline $1 / 2 \mathrm{RC}+\mathrm{Btk}$ & $1.6 \pm 1.60 \mathrm{Ac}$ & $3.2 \pm 1.50 \mathrm{ABc}$ & $68.4 \pm 5.21 \mathrm{Aa}$ & $26.0 \pm 4.18 \mathrm{Ab}$ & $99.2 \pm 0.80 \mathrm{~A}$ & 4.24 & 4.35 \\
\hline $\mathrm{RC}+\mathrm{Btk}$ & $3.5 \pm 1.83 \mathrm{Ac}$ & $4.12 \pm 1.20 \mathrm{ABc}$ & $67.2 \pm 8.81 \mathrm{Aa}$ & $19.5 \pm 5.30 \mathrm{Ab}$ & $94.3 \pm 3.94 \mathrm{~A}$ & 3.96 & 4.08 \\
\hline $2 \mathrm{RC}+\mathrm{Btk}$ & $0.0 \pm 0.00 \mathrm{Ac}$ & $1.6 \pm 0.96 \mathrm{ABc}$ & $71.1 \pm 4.42 \mathrm{Aa}$ & $25.8 \pm 4.62 \mathrm{Ab}$ & $98.5 \pm 0.93 \mathrm{~A}$ & 3.66 & 3.85 \\
\hline CV $1(\%)=$ & 36.5 & CV $2(\%)=$ & 30.8 & CV $3(\%)=$ & 11.8 & & \\
\hline \multicolumn{8}{|l|}{ Matan Plus } \\
\hline $\begin{array}{l}\text { Control } \\
\text { Water }\end{array}$ & $0.0 \pm 0.00 \mathrm{Aa}$ & $0.0 \pm 0.00 \mathrm{Aa}$ & $0.0 \pm 0.00 \mathrm{Ba}$ & $0.0 \pm 0.00 \mathrm{Ca}$ & $0.0 \pm 0.00 \mathrm{C}$ & 6.22 & 6.37 \\
\hline Control $1 / 2 \mathrm{RC}$ & $0.0 \pm 0.00 \mathrm{Aa}$ & $0.0 \pm 0.00 \mathrm{Aa}$ & $0.9 \pm 0.91 \mathrm{Ba}$ & $0.0 \pm 0.00 \mathrm{Ca}$ & $0.9 \pm 0.90 \mathrm{BC}$ & 5.64 & 5.53 \\
\hline Control RC & $0.0 \pm 0.00 \mathrm{Aa}$ & $0.0 \pm 0.00 \mathrm{Aa}$ & $0.0 \pm 0.00 \mathrm{Ba}$ & $0.0 \pm 0.00 \mathrm{Ca}$ & $0.0 \pm 0.00 \mathrm{C}$ & 5.54 & 5.53 \\
\hline Control 2RC & $5.6 \pm 3.51 \mathrm{Aa}$ & $0.0 \pm 0.00 \mathrm{Aa}$ & $0.0 \pm 0.00 \mathrm{Ba}$ & $0.0 \pm 0.00 \mathrm{Ca}$ & $5.6 \pm 3.50 \mathrm{~B}$ & 5.27 & 5.31 \\
\hline Control Btk & $3.2 \pm 1.50 \mathrm{Ab}$ & $2.4 \pm 0.99 \mathrm{Ab}$ & $48.1 \pm 5.11 \mathrm{Aa}$ & $41.2 \pm 4.29 \mathrm{Aa}$ & $95.0 \pm 2.14 \mathrm{~A}$ & 5.24 & 5.38 \\
\hline $1 / 2 \mathrm{RC}+\mathrm{Btk}$ & $1.6 \pm 1.60 \mathrm{Ab}$ & $0.0 \pm 0.00 \mathrm{Ab}$ & $56.1 \pm 5.80 \mathrm{Aa}$ & $39.2 \pm 5.75 \mathrm{Aa}$ & $96.9 \pm 1.89 \mathrm{~A}$ & 5.28 & 5.33 \\
\hline $\mathrm{RC}+\mathrm{Btk}$ & $3.1 \pm 1.44 \mathrm{Ac}$ & $6.2 \pm 3.11 \mathrm{Ac}$ & $65.9 \pm 8.25 \mathrm{Aa}$ & $21.3 \pm 7.09 \mathrm{Bb}$ & $96.5 \pm 1.61 \mathrm{~A}$ & 5.27 & 5.26 \\
\hline $2 \mathrm{RC}+\mathrm{Btk}$ & $5.0 \pm 1.57 \mathrm{Ac}$ & $6.1 \pm 3.79 \mathrm{Ac}$ & $60.4 \pm 8.59 \mathrm{Aa}$ & $26.0 \pm 4.96 \mathrm{ABb}$ & $97.5 \pm 1.72 \mathrm{~A}$ & 5.26 & 5.29 \\
\hline CV $1(\%)=$ & 27.9 & CV $2(\%)=$ & 34.9 & CV $3(\%)=$ & 11.1 & & \\
\hline \multicolumn{8}{|l|}{ Dalneem } \\
\hline $\begin{array}{l}\text { Control } \\
\text { Water }\end{array}$ & $0.0 \pm 0.00 \mathrm{Aa}$ & $0.0 \pm 0.00 \mathrm{Da}$ & $0.0 \pm 0.00 \mathrm{Ba}$ & $0.0 \pm 0.00 \mathrm{Da}$ & $0.0 \pm 0.00 \mathrm{C}$ & 6.22 & 6.37 \\
\hline Control $1 / 2 \mathrm{RC}$ & $0.0 \pm 0.00 \mathrm{Aa}$ & $0.0 \pm 0.00 \mathrm{Da}$ & $0.0 \pm 0.00 \mathrm{Ba}$ & $0.8 \pm 0.80 \mathrm{Da}$ & $0.8 \pm 0.80 \mathrm{C}$ & 5.05 & 5.02 \\
\hline Control RC & $0.9 \pm 0.87 \mathrm{Aa}$ & $1.1 \pm 1.11 \mathrm{CDa}$ & $0.0 \pm 0.00 \mathrm{Ba}$ & $1.9 \pm 1.15 \mathrm{Da}$ & $3.9 \pm 1.70 \mathrm{C}$ & 4.94 & 4.94 \\
\hline Control 2RC & $2.6 \pm 2.61 \mathrm{Ab}$ & $1.7 \pm 1.06 \mathrm{BCDb}$ & $2.5 \pm 1.01 \mathrm{Bb}$ & $11.3 \pm 2.98 \mathrm{Ca}$ & $18.2 \pm 5.95 \mathrm{~B}$ & 4.30 & 4.30 \\
\hline Control Btk & $3.9 \pm 3.10 \mathrm{Ac}$ & $7.2 \pm 1.32 \mathrm{Abc}$ & $70.6 \pm 3.37 \mathrm{Aa}$ & $17.4 \pm 2.19 \mathrm{BCb}$ & $99.1 \pm 0.86 \mathrm{~A}$ & 5.24 & 5.38 \\
\hline $1 / 2 R C+B t k$ & $0.8 \pm 0.77 \mathrm{Ad}$ & $6.1 \pm 1.86 \mathrm{ABCc}$ & $59.3 \pm 2.51 \mathrm{Aa}$ & $33.0 \pm 2.95 \mathrm{ABb}$ & $99.2 \pm 0.8 \mathrm{~A}$ & 5.05 & 5.30 \\
\hline $\mathrm{RC}+\mathrm{Btk}$ & $1.7 \pm 1.67 \mathrm{Ac}$ & $11.1 \pm 2.30 \mathrm{Ab}$ & $66.9 \pm 7.94 \mathrm{Aa}$ & $20.3 \pm 7.57 \mathrm{BCb}$ & $100.0 \pm 0.00 \mathrm{~A}$ & 5.04 & 5.54 \\
\hline $2 \mathrm{RC}+\mathrm{Btk}$ & $2.4 \pm 1.01 \mathrm{Ab}$ & $6.5 \pm 3.11 \mathrm{ABCDb}$ & $52.9 \pm 4.34 \mathrm{Aa}$ & $38.2 \pm 3.43 \mathrm{Aa}$ & $100.0 \pm 0.00 \mathrm{~A}$ & 5.02 & 5.33 \\
\hline CV $1(\%)=$ & 29.5 & CV $2(\%)=$ & 31.0 & CV $3(\%)=$ & 14.3 & & \\
\hline \multicolumn{8}{|l|}{ Pironim } \\
\hline $\begin{array}{l}\text { Control } \\
\text { Water }\end{array}$ & $0.0 \pm 0.00 \mathrm{Aa}$ & $0.0 \pm 0.00 \mathrm{Ba}$ & $0.0 \pm 0.00 \mathrm{Ba}$ & $0.0 \pm 0.00 \mathrm{Ba}$ & $0.0 \pm 0.00 \mathrm{C}$ & 6.22 & 6.37 \\
\hline Control $1 / 2 \mathrm{RC}$ & $2.3 \pm 0.93 \mathrm{Aa}$ & $0.0 \pm 0.00 \mathrm{Ba}$ & $0.8 \pm 0.83 \mathrm{Ba}$ & $0.0 \pm 0.00 \mathrm{Ba}$ & $3.1 \pm 0.79 \mathrm{C}$ & 3.71 & 3.64 \\
\hline Control RC & $1.7 \pm 1.02 \mathrm{Aa}$ & $0.0 \pm 0.00 \mathrm{Ba}$ & $0.8 \pm 0.83 \mathrm{Ba}$ & $0.0 \pm 0.00 \mathrm{Ba}$ & $2.5 \pm 1.66 \mathrm{C}$ & 3.55 & 3.54 \\
\hline Control 2RC & $3.8 \pm 1.11 \mathrm{Aa}$ & $1.7 \pm 1.74 \mathrm{Aba}$ & $2.6 \pm 1.73 \mathrm{Ba}$ & $3.4 \pm 1.46 \mathrm{Ba}$ & $11.5 \pm 3.72 \mathrm{~B}$ & 3.43 & 3.44 \\
\hline Control Btk & $3.9 \pm 3.10 \mathrm{Ab}$ & $7.2 \pm 1.32 \mathrm{Ab}$ & $70.6 \pm 3.37 \mathrm{Aa}$ & $17.4 \pm 2.19 \mathrm{Ab}$ & $99.1 \pm 0.86 \mathrm{~A}$ & 5.24 & 5.38 \\
\hline $1 / 2 \mathrm{RC}+\mathrm{Btk}$ & $1.5 \pm 1.54 \mathrm{Ac}$ & $3.0 \pm 1.82 \mathrm{Abc}$ & $62.6 \pm 11.07 \mathrm{Aa}$ & $31.5 \pm 2.00 \mathrm{Ab}$ & $98.6 \pm 0.88 \mathrm{~A}$ & 3.80 & 3.95 \\
\hline $\mathrm{RC}+\mathrm{Btk}$ & $0.0 \pm 0.00 \mathrm{Ac}$ & $6.1 \pm 2.00 \mathrm{Abc}$ & $64.8 \pm 8.71 \mathrm{Aa}$ & $25.3 \pm 7.48 \mathrm{Ab}$ & $96.2 \pm 2.62 \mathrm{~A}$ & 3.73 & 4.00 \\
\hline $2 \mathrm{RC}+\mathrm{Btk}$ & $3.1 \pm 1.93 \mathrm{Ac}$ & $6.7 \pm 2.71 \mathrm{Abc}$ & $58.3 \pm 8.25 \mathrm{Aa}$ & $29.6 \pm 6.98 \mathrm{Ab}$ & $97.7 \pm 2.22 \mathrm{~A}$ & 3.51 & 3.62 \\
\hline CV $1(\%)=$ & 35.6 & CV $2(\%)=$ & 40.2 & CV $3(\%)=$ & 10.1 & & \\
\hline \multicolumn{8}{|l|}{ Stubble-Aid $^{\circledR}$} \\
\hline $\begin{array}{l}\text { Control } \\
\text { Water }\end{array}$ & $0.0 \pm 0.00 \mathrm{Aa}$ & $0.0 \pm 0.00 \mathrm{Aa}$ & $0.0 \pm 0.00 \mathrm{Ca}$ & $0.8 \pm 0.80 \mathrm{Ca}$ & $0.8 \pm 0.80 \mathrm{~B}$ & 6.22 & 6.37 \\
\hline Control $1 / 2 \mathrm{RC}$ & $0.0 \pm 0.00 \mathrm{Aa}$ & $0.0 \pm 0.00 \mathrm{Aa}$ & $0.8 \pm 0.80 \mathrm{Ca}$ & $0.0 \pm 0.00 \mathrm{Ca}$ & $0.8 \pm 0.80 \mathrm{~B}$ & 3.45 & 3.48 \\
\hline Control RC & $0.0 \pm 0.00 \mathrm{Aa}$ & $0.8 \pm 0.80 \mathrm{Aa}$ & $0.8 \pm 0.80 \mathrm{Ca}$ & $1.6 \pm 0.98 \mathrm{Ca}$ & $3.2 \pm 1.96 \mathrm{~B}$ & 3.33 & 3.29 \\
\hline Control 2RC & $0.0 \pm 0.00 \mathrm{Aa}$ & $0.8 \pm 0.80 \mathrm{Aa}$ & $0.0 \pm 0.00 \mathrm{Ca}$ & $0.0 \pm 0.00 \mathrm{Ca}$ & $0.8 \pm 0.80 \mathrm{~B}$ & 3.18 & 3.13 \\
\hline Control Btk & $0.0 \pm 0.00 \mathrm{Ac}$ & $0.8 \pm 0.80 \mathrm{Ac}$ & $36.4 \pm 5.20 \mathrm{Bb}$ & $58.8 \pm 5.63 \mathrm{Aa}$ & $96.0 \pm 1.79 \mathrm{~A}$ & 5.24 & 5.38 \\
\hline $1 / 2 R C+B t k$ & $0.0 \pm 0.00 \mathrm{Ab}$ & $0.7 \pm 0.71 \mathrm{Ab}$ & $48.8 \pm 12.57 \mathrm{ABa}$ & $40.9 \pm 8.86 \mathrm{Aa}$ & $90.4 \pm 6.01 \mathrm{~A}$ & 3.89 & 3.70 \\
\hline $\mathrm{RC}+\mathrm{Btk}$ & $0.0 \pm 0.00 \mathrm{Ab}$ & $2.1 \pm 2.09 \mathrm{Ab}$ & $55.2 \pm 6.11 \mathrm{ABa}$ & $39.5 \pm 6.95 \mathrm{Aa}$ & $96.8 \pm 3.20 \mathrm{~A}$ & 3.62 & 3.60 \\
\hline $2 \mathrm{RC}+\mathrm{Btk}$ & $1.6 \pm 1.60 \mathrm{Ac}$ & $3.9 \pm 1.76 \mathrm{Ac}$ & $63.6 \pm 7.52 \mathrm{Aa}$ & $20.4 \pm 3.10 \mathrm{Bb}$ & $89.6 \pm 6.65 \mathrm{~A}$ & 3.54 & 3.66 \\
\hline CV $1(\%)=$ & 28.6 & CV $2(\%)=$ & 34.3 & CV $3(\%)=$ & 13.2 & & \\
\hline
\end{tabular}

Means $( \pm$ SE) followed by the same uppercase on the line and lowercase on the column in the row do not differ significantly by Tukey test $(\mathrm{P}<0.05)$ Product concentration: $1 / 2 \mathrm{RC}=$ Half the recommended concentration, $\mathrm{RC}=$ Recommended concentration; $2 \mathrm{RC}=$ Twice the recommended concentration.

${ }^{1}$ Total percentage of larvae mortality over 72 hours.

Treatment $1=\mathrm{CV}, \mathrm{CV}=$ Time $2, \mathrm{CV}=3$ Total mortality.

CV 1 = Treatment; CV 2 = Time; CV 3 = Total mortality.

Source: Elaboration of the authors. 
According to Lecadet and De Donder (1967), cited by Habib and Andrade (1998), toxins resulted from crystal hydrolysis from semipurified protease were lethal to larvae of Pieris brassicae whereas toxins from dissolution in alkaline media did not show the same effect. According to El-Moursy, Sharaby and Awad (1993) copper sulphate, a substance present in Bordeaux mixture, mixed with Btk crystals and added to the artificial diet of rice moth Corcyra cephalonica reduced larvae mortality when compared to those fed diets containing only Btk crystals.

The $\mathrm{pH}$ did not seem to have influenced any of the negative effects presented by other treatments because the results were lower than the control treatment with Btk and similar to other treatments that did not affect toxicity.

However, this difference in mortality occurred because both products are insecticides and the higher concentrations tested were toxic to the caterpillars. Bovemax is also an insecticide, based on $B$. bassiana conidia, but no significant mortality was observed in any of the concentrations, according to Alves (1998) fungi require long time to act, therefore the time for conidia to act on the larvae must be longer than $72 \mathrm{~h}$, the period of observation of this study. Still, the studied insect may not be susceptible to the fungus from which Bovemax is made.

Biogermex presented mortality reduction at 48 $\mathrm{h}$ in $\mathrm{RC}+\mathrm{Btk}$ and $2 \mathrm{RC}+\mathrm{Btk}$ probably due to the presence of any compound of this product, which delayed the action of crystals because no significant difference was observed in total mortality between treatments and control treatment with Btk.

The decision to use an entomopathogen in the field must consider not only the ability to reduce the target insect population, but also the persistence in the environment. Entomopathogens multiply within the host, thus they must be kept active until the target insect is reached (BATISTA FILHO et al., 1998). Therefore, among the tested products, Matan Plus, regardless of concentration, is the most suitable to be used in association with Btk without compromising spores and crystals toxicity.

\section{Conclusions}

Except Matan Plus, the other studied natural products affected negatively the $\mathrm{CFU} / \mathrm{ml}$ formation,. Bordeaux mixture, regardless of concentration, was the only product that affected the crystals toxicity on A. gemmatalis.

\section{Acknowledgements}

Thanks to $\mathrm{CNPq}$ for IC and productivity fellowships; the Biologist Andrea K. Bonini for assistance in statistical analysis; Prof. José Renato Stangarlin for providing samples of the products tested; EMBRAPA - Empresa Brasileira de Pesquisa Agropecuária (Soybean unit) for providing the insects used in the experiments; Katia AtojiHenrique for reviews in English.

\section{References}

ALMEIDA, J. E. M.; BATISTA FILHO, A.; LAMAS, C.; LEITE, L. G.; TRAMA, M.; SANO, A. H. Avaliação da compatibilidade de defensivos agrícolas na conservação de microrganismos entomopatogênicos no manejo de pragas do cafeeiro. Arquivos do Instituto Biológico, São Paulo, v. 70, n. 1, p. 79-84, 2003.

ALVES, S. B. Fungos entomopatogênicos. In: Controle microbiano de insetos. 2. ed. Piracicaba: FEALQ, 1998. p. 289-381.

ALVES, S. B.; MOINO JÚNIOR, A.; ALMEIDA, J. E. M. Produtos fitossanitários e entomopatógenos. In: ALVES, S. B. (Ed.). Controle microbiano de insetos. 2. ed. Piracicaba: FEALQ, 1998. p. 217-238.

ALVES, S. B.; MORAES, S. A. Quantificação de inóculo de patógenos de insetos. In: ALVES, S. B. (Ed.). Controle microbiano de insetos. 2. ed. Piracicaba: FEALQ, 1998. p. 765-797.

ALZOREKY, N. S.; NAKAHARA, K. Antibacterial activity of extracts from some edible plants commonly consumed in Asia. International Journal of Food Microbiology, Amsterdam, v. 80, n. 3, p. 223-230, 2003. 
ANGELO, E. A.; VILAS-BÔAS, G. T. V.; CASTROGÓMEZ, R. J. H. Bacillus thuringiensis: características gerais e fermentação. Semina: Ciências Agrárias, Londrina, v. 31, n. 4, p. 945-958, out./dez. 2010.

BATISTA FILHO, A.; ALMEIDA, J. E. M.; LAMAS, C. Effect of thiamethoxam on entomopathogenic microorganisms. Neotropical Entomology, Londrina, v. 30, n. 3, p. 437-447, 2001.

BATISTA FILHO, A.; ALVES, S. B.; ALVES, L. F. A.; PEREIRA, R. M.; AUGUSTO, N. T. Formulação de entomopatógenos. In: ALVES, S. B. (Ed.). Controle microbiano de insetos. 2. ed. Piracicaba: FEALQ, 1998. p. 917-965.

CHEN, K.; FUNKE, B. R.; SCHULZ, J. T.; CARLSON, R. B.; PROSHOLD, F. I. Effects of certain organophosphate and carbamate inseticides on Bacillus thuringiensis. Journal of Economic Entomology, Lanham, v. 67, n. 4, p. 471-473, 1974.

COWAN, M. M. Plant products as antimicrobial agents. Clinical Microbiology Reviews, Washington, v. 12, n. 4, p. 564-582, 1999.

DIXON, R. A.; DEY, P. M.; LAMB, C. J. Phytoalexins: enzymology and molecular biology. Advanced Enzymology, New York, v. 55, p. 1-69, 1983.

DOUGHERTY, E. M.; REICHELDERFER, C. F.; FAUST, R. M. Sensitivity of Bacillusthuringiensis var. thuringiensis to various insecticides and herbicides. Journal of Invertebrate Pathology, United States, v. 17, n. 2, p. 292-293, 1971.

EL-MOURSY, A. A.; SHARABY, A.; AWAD, H. H. Some chemical additives to increase the activity spectrum of Bacillus thuringiensis var. kurstaki (Dipel 2x) against the rice moth Corcyra cephalonica. Journal of Islamic Academy of Sciences, Turkey, v. 6, n. 2, p. 149-154, 1993.

FERREIRA, D. F. Sisvar: sistema de análise de variância para dados balanceados, versão 5.1 Build 72. Lavras: DEX/ UFLA, 2007. (Software).

GALLO, D.; NAKANO, O.; SILVEIRA NETO, S.; CARVALHO, R. P. L.; BAPTISTA, G. C.; BERTI FILHO, E.; PARRA, J. R.; ZUCCHI, R. A.; ALVES, S. B.; VENDRAMIN. J. D.; MARCHINI. J. D.; LOPES, J .R. S.; OMOTO, C. Métodos de controle de pragas. In: Manual de entomologia agrícola. Piracicaba: FEALQ, 2002. cap. 10, p. 243-359.

GASSEN, M. H.; BATISTA FILHO, A.; ZAPPELINI, L. O. Avaliação da compatibilidade de fungicidas e inseticidas com a bactéria entomopatogênica, Bacillus thuringiensis, em laboratório. In: REUNIÃO ANUAL DO INSTITUTO BIOLÓGICO, 19., 2006. São Paulo. Anais... São Paulo: Instituto Biológico, 2006. p. 1-4.
GENENA, A. K.; HENSE, H.; SMÂNIA JUNIOR, A. SOUZA, S. M. Rosemary (Rosmarinus officinalis): a study of the composite on, antioxidant and antimicrobial activities of extracts obtained with supercritical carbon dioxide. Ciência e Tecnologia de Alimentos, Campinas, v. 28, n. 2, p. 463-469, 2008.

HABIB, M. E. M.; ANDRADE, C. F. S. Bactérias entomopatogênicas. In: ALVES, S. B. (Ed.). Controle microbiano de insetos. 2. ed. Piracicaba: FEALQ, 1998. p. 383-446.

HASSEN, A.; SAIDI, N.; CHERIF, M.; BOUDABOUS, A. Resistance of environmental bacteria to heavy metals. Bioresource Technology, Essex, v. 64, n. 1, p. 7-15, 1998.

HOFFMANN-CAMPO, C. B.; OLIVEIRA, E. B.; MOSCARDI, F. Criação massal da lagarta da soja (Anticarsia gemmatalis). Londrina: EMBRAPA - Centro Nacional de Pesquisa da Soja, 1985. 21 p. (Documentos, 10).

JIMENEZ, J.; ACOSTA, N.; FERNANDEZ, R. Efecto de insecticidas y fungicidas sobre la actividade biologica de preparaciones de Bacillus thuringiensis. Protección de Plantas, Cuba, v. 12, n. 1, p. 45-59, 1989.

KRISCHIK, V. A.; BARBOSA, P.; REICHELDERFER, A. F. Three trophic level interactions: allelochemicals, Manduca sexta (L.), and Bacillus thuringiensis var. kurstaki berliner. Environmental Entomology, Iowa, v. 17, n. 3, p. 476-482, 1988.

LACEY, L. A.; FRUTOS, R.; KAYA, H. K.; VAIL, P. Insect pathogens as biological control agents: do they have a future? Biological Control, Orlando, v. 21, n. 3, p. 230-248, 2001.

MENDES, Z. F.; LIMA, E. R.; FRANCO, E. S.; OLIVEIRA, R. A.; ALEIXO, G. A. S.; MONTEIRO, V. L.; MOTA, R. C.; COELHO, M. C. O. C. Avaliação da atividade antimicrobiana da tintura e pomada de Ruta graveolens (Arruda) sobre bactérias isoladas de feridas cutâneas em cães. Medicina Veterinária, Pernambuco, v. 2, n. 3, p. 32-36, 2008.

MORRIS, O. N. Effect of some chemical insecticides on the germination and repelication of commercial Bacillus thuringiensis. Journal of Invertebrate Pathology, United States, v. 26, n. 3, p. 199-204, 1975.

MOSSINI, S. A. G.; KEMMELMEIER, C. A árvore Nim (Azadirachta indica. A. Juss.): múltiplos usos. Acta Farmaceutica Bonaerense, Buenos Aires, v. 24, n. 1, p. 139-148, 2005.

MOTOYAMA, M. M.; SCHWAN-ESTRADA, K. R. F.; STANGARLIN, J. R.; FIORI, A. C. G.; SCAPIM, C. A. Efeito antimicrobiano de extratos cítricos sobre Ralstonia solanacearum e Xanthomonas axonopodis pv. 
manihotis. Acta Scientiarum. Agronomy, Maringá, v. 25, n. 2, p. 509-512, 2003.

PEREIRA, M. S. V.; RODRIGUES, O. G.; FEIJO, F. M. C.; ATHAYDER, A. N. C.; LIMA, E. Q.; SOUSA, M. R. Q. Atividade antimicrobiana de extratos de plantas no Semi-Árido Paraibano. Agropecuária Científica no Semiárido, Patos, v. 2, n. 1, p. 37-44, 2006.

SALERNO, C.; DIAS, S.; SAGARDOY, M. Efecto de pesticidas sobre cepas de Bacillus thuringiensis bajo condiciones controladas. Revista Argentina de Microbiologia, Argentina, v. 31, n. 2, p. 58-64, 1999.

SILVA, E. R. L.; ALVES, L. F. A.; SANTOS, J.; POTRICH, M.; SENE, L. Técnicas para avaliação do efeito in vitro de herbicidas sobre Bacillus thuringiensis var. kurstaki. Arquivos do Instituto Biológico, São Paulo, v. 75, n. 1, p. 59-67, 2008.

SILVA, E. R. L; ALVES, L. F. A.; SENE, L.; SANTOS, J. C.; BONINI, A. K.; POTRICH, M.; NEVES, P. M. O. J. Técnicas para avaliação do efeito "in vitro" de fungicidas sobre Bacillus thuringiensis var. kurstaki. Arquivos do Instituto Biológico, São Paulo, v. 73, n. 4, p. 429-437, 2006.
SUTTER, G. R.; ABRAHANSON, M. D.; HAMILTON, E. W.; VICK, I. D. Compatibility of Bacillus thuringiensis var. kurstaki and chemical inseticides. 1. Effect of Insecticide doses on bacterial replication rate. Journal of Economic Entomology, Baltimore, v. 64, n. 6, p. 13481350, 1971.

TSUCHIYA, H.; SATO, M.; MIYAZAKI, T.; FUJIWARA, S.; TANIGAKI, S.; OHYAMA, M.; TANAKA, T.; LINUMA, M. Comparative study on the antibacterial activity of phytochemical flavanones against methicillin-resistant Staphylococcus aureus. Journal Ethnopharmacol, Ireland, v. 50, n. 1, p. 27-34, 1996.

VENKAT, R. S.; PULlELA, S.; PRAVEEN, B.; KISHORE, K.; CHINA, B.; SURYANARAYANA, U.; MADHUSUDANA, J. Antibacterial constituents from the berries of Pipper nigrum. Phytomedicine, Jena, v. 11, n. 7-8, p. 697-700, 2004. 
